\title{
LEGAL DUE DILIGENCE OF FINTECH LAW OF AGREEMENTS TRANSFORMATION OF ECONOMIC RECOVERY IN THE NEW NORMAL ERA
}

\author{
Yapiter Marpi \\ Universitas Jakarta \\ e-mail: yapitermarpi@gmail.com
}

\begin{abstract}
Article Info
Keyword:

Legal Transformation;

Due Diligence;

Economic Recovery.
\end{abstract}

\begin{abstract}
One of the economic activities as distribution of funds must be carried out fairly and according to Article 33 paragraph (4) of the 1945 Constitution is the economy. Financing Institutions have undergone a process of digitization, and during the Covid-19 pandemic, experienced a high surge in business capital needs so that financing transactions can be easily accessed online, financial technology (fintech) regulated in OJK Regulation No.77 / POJK.01 / 2016 concerning Borrowing Services Information Technology-Based Borrowing. The research method used is through normative law and conceptually socio-legal. The results of this research analysis are expected that business people who want to invest in a company services can transform in a Legal Due Diligence so that the economic recovery on economic democracy using the principles of togetherness, justice, sustainability environmental awareness, independence. Legal Due Diligence is able to be a solution to minimize potential risks in the future.
\end{abstract}

\section{Article Info}

\section{Kata Kunci:}

Transformasi Hukum;

Uji Tuntas;

Pemulihan Ekonomi.

\begin{abstract}
Abstrak
Salah satu kegiatan ekonomi sebagai penyaluran dana yang harus dilakukan secara adil dan sesuai dengan Pasal 33 ayat (4) UUD 1945 yaitu perekonomian. Lembaga Pembiayaan telah mengalami proses digitalisasi, ditambah lagi pada masa pandemi Covid-19 mengalami lonjakan kebutuhan modal usaha yang tinggi sehingga transaksi pembiayaan dapat dengan mudah diakses secara online, layanan financial technology (fintech) diatur dalam Peraturan OJK No.77/POJK .01/2016 tentang Layanan Pinjam Meminjam Uang Berbasis Teknologi Informasi. Metode penelitian yang digunakan adalah melalui hukum normatif dan secara konseptual socio legal. Hasil analisis penelitian ini diharapkan para pelaku bisnis mau berinvestasi di perusahaan dengan proses yang cepat, sehingga kebutuhan akan layanan Fintech mampu bertransformasi secara Legal Due Diligence sehingga pemulihan ekonomi era nasional baru berjalan lancar. diselenggarakan berdasarkan demokrasi ekonomi dengan prinsip kebersamaan, keadilan, keberlanjutan, kepedulian lingkungan, kemandirian. Legal Due Deligence mampu risiko di kemudian hari. Sehingga akan mendapatkan keuntungan bagi penyelenggara finctech implikasi positif dari konsep bisnis Legal Due Deligence.
\end{abstract}

\section{Introduction}

The development of the internet, which is quite rapid and widespread, requires technology and information to continue providing innovation to the community. In the business sector, start-up 
business development is the one that has experienced much improvement. With the increasing number of victims and property losses, as well as the expansion of the exposed area, as well as having implications for broad socio-economic aspects in Indonesia, Presidential Decree No. 12 of 2020 concerning Determination of Non-Natural Disasters for the Spread of Corona Virus Disease 2019 was issued, hereinafter referred to as COVID-19 as a National Disaster. However, the development of Fintech in Indonesia remains under the supervision of Bank Indonesia (BI) as the central bank. The innovation that develops here is the adaptation of computer network principles applied to the financial sector although initially the Peer to Peer financial concept was intended for start-ups (new entrepreneurs) in seeking investors to finance their business. As a form of application of information technology in the financial sector. Fintech has various functions, which are believed to be able to quickly develop rapidly.(Marpi, 2021)

Research in fintech usually begins with the evaluation of fintech (including mechanical and financial devices) and the social and ethical impacts of the robots' use. We also consider fintech as coordinating financial technology because it can provide added value to financial services. Advances in technology in the design and delivery of financial products and their applications require the monitoring, management, and control of financial services to be implemented to achieve effective objectives in the financial sector to pursue compliance and reporting. A lot of research focused on fintech recruitment from both technology and user perception perspectives.

Currently, fintech is able to serve electronic money, virtual accounts, aggregators, lending, crowdfunding, and other online financial transactions. In some fintech industries that have been operating, some were established by conventional-based companies, but not a few are start-ups. The development and growth of Fintech in Indonesia then require Indonesia to make strict rules to monitor and regulate the sustainability of Fintech in Indonesia. The start-up business that is currently increasing the most is the Fintech (Financial Technology) business. Fintech itself aims to provide convenience for the public in carrying out financial transactions online. Fintech comes along with changes in people's lifestyles that are increasingly attached to fast-paced information technology. The presence of fintech itself makes it very easy for people to use products and makes it easier for people to make deals in the financial sector. Fintech in Indonesia, as defined in Bank Indonesia Regulation number 19/12/PBI/2017, is the use of financial system technology that produces new products, services, technology, and/or business models and can have an impact on monetary stability, financial system stability, efficiency, smoothness, security, and reliability of the payment system. Peer-to-peer lending provides innovation in lending and borrowing because there is no need to meet in person but through an application or website. The impact on credit or financing during the Covid-19 pandemic occurred because people had difficulty fulfilling their achievements (Silalahi, 2021).

Several possibilities occur, such as being late in fulfilling achievements and the risk of default by the borrower. Financial technology management is in payment systems, market support, investment management and risk management, loans, fund financing, capital providers, and other financial services. Online-based lending is carried out by financial technology that makes it easier for the public to access financial products. One of the products produced is an information technologybased lending and borrowing service called Peer to Peer Lending. Fintech is a new business model that provides convenience in meeting people's needs in their financial system. Although fintech is not a banking service, it is regulated by Bank Indonesia and must be officially registered in the Financial Services Authority (OJK). Although fintech is very profitable for the Indonesian economy, fintech also has some risks which violate the law because it involves many legal subjects, such as criminal, civil, and administrative violations (Sitompul, 2018).

Indonesian financial technology has many violations, such as consumer rights infringement, personal data infringement, and illegal financial technology. The cases above should receive special attention, especially on the aspects of legal guarantees and the validity of online loans. Regarding the application-based money lending services or information technology above, it is regulated in the Financial Services Authority Regulation Number 77/POJK.01/2016 of 2016 concerning Information 
Technology-Based Borrowing and Borrowing Services and Bank Indonesia Regulation Number 19/12/PBI/2017 of 2017 concerning Implementation of Financial Technology. (Istiqamah, 2019)

Application-based or information technology-based lending services are one type of Financial Technology (Fintech) in the category of Financial/Other Financial Services. In conducting its business, the operator is required to apply for registration and licensing to the Financial Services Authority (OJK). The loan amount determined by the OJK in the implementation of application-based lending and borrowing services is a maximum of IDR 2 billion. Of course, these violations are also increasingly risky because of the Covid-19 national disaster, which is still experiencing a very high increase. The risk of this violation can be triggered by the termination of employment in many companies, resulting in many people no longer having income but still having expenses to fulfill their daily needs. A fair legal protection and legal certainty must also accompany credit activities using online media to create fair competition and comfort creditors and debtors in these activities (Vedian, 2017).

The convenience in question is that the debtor gets a guarantee related to the confidentiality of personal data and all forms of guarantees because the risk of being spread in public is very easy through online media. Likewise, creditors must feel calm and safe in running their business because the online credit process is not done face-to-face, so the process of checking or checking guarantees and ability to pay becomes challenging to analyze. The impact experienced by the community becomes more complex with the existence of these policies. The community is increasingly limited in carrying out their activities. The sectors affected include the political, economic, tourism, and other sectors. From the various sectors, the economy has experienced a fairly large impact. The most popular economic activity carried out by the community is credit application. Credit provision is carried out in banks and financial institutions and now has high demand, online-based borrowing.

\section{Methodology}

This research uses normative juridical research, an approach based on studying and discussing legal rules, doctrines, or principles in legal science by examining library materials or researching libraries. Normative research is the process of obtaining laws, legal principles, and legal doctrines, in order to answer developing legal problems. This normative legal research is carried out to obtain legal opinions, theories, and new concepts as legal guidelines for overcoming legal problems. Legal research is based on literature, legal theory, and legislation existing in society from the highest to the lowest. The problems in this study will be studied from the relevant legal provisions, regulated them, and then analyzed to make legal discoveries related to legal issues in these regulations. In addition, the author also uses a statutory approach, which is an approach that uses positive legislation as a medium of analysis. As well as using a conceptual approach, which is an approach that uses legal concepts as a starting point for analyzing legal problems that occur.(Soekanto, 2010)

The main process carried out in this normative research is to conduct research on the regulations of the Financial Services Authority and Bank Indonesia regulations related to Fintech in Indonesia. The primary legal material used in this research is the Financial Services Authority Regulation and Bank Indonesia Regulation, while the secondary material used in this research is the Personal Data Protection Bill. Therefore, the data collection technique used in this research is a literature study carried out by reading, exploring, taking notes, and analyzing library materials that have a relationship with fintech. The data processing used in this research is to systematize existing legal materials, then analyze the problem using legal materials (Ali, 2011). 


\section{Results and Discussion}

Legal Substance or Legal Substance Problems in Providing Legal Protection Efforts to the Parties

\section{Against Peer to Peer Lending Fintech Entities}

Based on the theory of Lawrence M. Friedman, legal substance is the rules, norms, and patterns of real human behavior that are in the system. So the substance of the law concerns the applicable laws and regulations that have binding power and become guidelines for law enforcement officers. Legal substance or what is commonly called legal substance is an important element determining whether the law can be implemented. For the goals and objectives to be achieved from banking through Customer Due Diligence, the bank will cooperate with the authorities, which are law enforcement officers, and the Financial Transaction Reports and Analysis Center (Dewi Sartika Saimima , I., 2021). The Financial Transaction Reports and Analysis Center is an independent institution responsible for the President of the Republic of Indonesia, which was established in order to fulfill Article 16 of The Forty Recommendations made by the Financial Action Task Force On Money Laundering (FATF). The Financial Services Authority and Bank Indonesia have each issued regulations to protect consumers in fintech. Financial Services Authority Regulation 77/POJK.01/2016 concerning information technology-based lending and borrowing services is presented to protect consumers from the emergence of harmful actions against their data and funds. This regulation was also issued to protect consumers from money laundering and terrorism financing, financial system stability, and regulate the managers of fintech companies. Bank Indonesia also issued regulations through Bank Indonesia Regulation (PBI) number 19/12/PBI/2017 regarding the implementation of financial technology to support the creation of financial stability, financial stability, and provide guarantees to the public that the payment system is effective, safe, problemfree and credible. This regulation is considered unable to protect all parties in Peer-to-peer lending because it does not provide credit guarantees in the loan agreement. In peer-to-peer lending, of course, the lender also bears a significant risk in the event of a default by the borrower resulting in default. So because there are no rules regarding loan guarantees, the lender must accept all possible risks of losing funds. This unregulated lending and borrowing credit guarantee also result in uncertainty of funds that can be borrowed. From the borrower's side, the possibility of being given a loan as requested is entirely uncertain because the decision to grant the loan amount is entirely on the lender's side (Freedman, 2015).

\section{Against Peer to Peer Lending Fintech Consumers}

Various cases are arising in society as a result of the presence of fintech, such as high taxes by fintech, debt collection that is not following procedures, collection of personal data, criminal acts of threats, even in some cases followed by criminal acts of sexual harassment. The number of Fintech cases, which are illegal and violate consumer rights, really needs to get the Government's attention because they involve many people's lives in all social strata of society, even though lower social classes mostly experience them. This, of course, happens because of the lack of knowledge in the transaction using technology that is developing quite rapidly, and because it attracts people easily for the loan disbursement process takes 15 to 20 minutes. One of the things that also causes the rise of illegal and problematic fintech is that the Indonesian people's reading competence is relatively low. As explained by UNESCO in 2016, the reading interest of Indonesian is very alarming, only about $0.001 \%$. It means out of 1000 people in Indonesia, only one person is interested in reading. Meanwhile, as is known, every website or application provided by a fintech displays terms and conditions before entering and registering to the website (Cahya, Kadek Adnan Dwi; Kasih, Desak Putu Dewi; Sutama, 2018).

Regulations issued by the Financial Services Authority and Bank Indonesia are still considered administrative, which means that law violation by fintech and the sanctions that can be imposed according to these regulations cannot protect all consumer rights. It happens because the regulations issued by the Financial Services Authority do not have criminal sanctions or fines for 
violation by fintech. The maximum sanctions issued are only revocation of registration marks and registration permits (Herowati Poesoko, 2020).

\section{Solutions in overcoming problematic fintech}

Articles were grouped by location according to the author's location and the location of the case study. This group aims to identify trends and topics of interest in one place. In addition to global (excluding specific regions), we have divided locations into continents: Asia, Europe, Americas, Africa, and Australia. From the data obtained, the Asian continent ranked first in the survey of fintech. These included studies from some countries, China (20 studies), Indonesia (19 studies), and South Korea (9 studies). In addition, there are studies from other countries such as Taiwan, Malaysia, India, Japan, Singapore, Thailand and Brunei. Therefore, the solution to overcoming problematic and illegal fintech can be through institutions engaged in financial services such as the OJK, and regulations that prevent the emergence of problematic Fintech and illegal Fintech such as Ministerial Regulations and Laws.

\section{Financial Services Authority}

As explained in the issue above, these illegal fintech websites and applications explain in terms and condition that they can access all consumers' personal data, even contacts stored in the consumer's phone book. However, the low willingness to read from the public causes much retrieval of personal data from consumers not known by consumers and causes other criminal acts. To prevent that, the Ministry of Communication and Information (Kominfo) can block illegal fintech. In addition to blocking, another thing that is also considered to have a major influence on eradicating illegal fintech is socialization and education to increase public understanding of the industry engaged in financial services. The OJK collaborates with the local government, financial service institutions (LJK) agencies, and agencies related to the financial services sector(Dwi Nugrahayu Devianti, Prija Djatmika, 2020).

\section{Personal Data Protection Bill}

The danger of the absence of legal rules in the protection of personal data will harm consumers caused by: many threats from breaking into or stealing consumers' data outside due to the company's negligence which lacks good data protection and privacy systems implemented by fintech or the dangers of people working in fintech industry who deliberately take personal data. Threats to consumers' data can also be done by workers at fintech companies intending to take users' digital data for their needs and interests. This threat can cause fintech that has developed rapidly in Indonesia to get a negative image from other countries that have already made regulations that protect the personal data of their better and more competent people, both from users and potential users of fintech services. Therefore, the Personal Data Bill (RUU PDP) which is currently in the discussion stage and has been included in the DPR Prolegnas, is expected to provide effective results in overcoming the existence of illegal fintech causing harm to the community. With the PDP Bill, it is considered to be able to provide protection for public data in the fintech ecosystem in Indonesia. The protection of personal data is essential because it concerns the issue of the rights inherent in a person as regulated by the GDPR (General Data Protection Regulation) in the European Union and covers all regions that accept the presence of European Union citizens. Therefore, at least four things from the GDPR are considered to be included in the PDP Bill (Marta Widian Sari, 2020).

\section{Conclusion}

The author concludes the implementation of finctech agreements that are better to use due diligence, such as:

First, regulations for business actors who process users' personal data digitally and as the first party which is a provider of fintech lending and loan creditors called third parties. With strict rules, it forces fintech providers and loan creditors to become increasingly responsible for the personal data of fintech business users that have been submitted to them. 
Second, clear rules for processing users' personal data should be provided. OJK only grants access to three features for fintech lending business players, namely the camera, microphone, and user location. The relevance of using these three features is the implementation of E-KYC (Electronic-Know Your Customer). With the provision of restrictions on access to user data processing, the public is able to see and analyze the characteristics of legal and illegal fintech.

Third, consumer data used by fintech business actors must provide a time limit for use so that the data cannot be stored for a long time by the fintech business actor. The data storage used must be limited to six to twelve months. It is of course to avoid the misuse of fintech users' personal data that fintech providers no longer use.

Fourth, the organizer must provide facilities for users to delete their own personal data that has been submitted to the fintech business actor. It is hoped that the ease of accessing and using digital data is as easy as deleting the user's personal data

\section{References}

Ali, Z. (2011). Metode Penelitian Hukum. Sinar Grafika.

Cahya, Kadek Adnan Dwi; Kasih, Desak Putu Dewi; Sutama, I. B. P. (2018). Penerapan Prinsip Customer Due Diligence Dan Enhanced Due Diligence Dalam Pencegahan Pencucian Uang Pada Bank Rakyat Indonesia. Kertha Semaya: Journal Ilmu Hukum, 5(1). https://doi.org/https://ojs.unud.ac.id/index.php/kerthasemaya/article/view/43505

Dewi Sartika Saimima , I., \& G. P. (2021). The Fintech Phenomenon: Protection of Consumer Privacy Data in Online Lending. Jurnal Kajian Ilmiah, 21(2), 185-194. https://doi.org/https://doi.org/10.31599/jki.v21i2.564

Dwi Nugrahayu Devianti, Prija Djatmika, S. S. (2020). The Risks Of Personal Data Theft In FintechBased Online Loan Applications Due To The Absence Of Law In Indonesia. Jurisdictie, 11(2), 9-21. https://doi.org/https://doi.org/10.18860/j.v11i2.7921

Freedman, D. M. D. M. R. N. (2015). Equity Crowdfunding for Investors : A Guide to Risks, Returns, Regulations, Funding Portals, Due Diligence, and Deal Terms. John Wiley \& Sons Inc.

Herowati Poesoko, A. A. S. L. D. (2020). The Role of Legal Opinion as Legal Problem Solving Method. Sociological Jurusprudence Journal, 3(1), 19-27. https://doi.org/https://doi.org/10.22225/scj.3.1.1513.19-27

Istiqamah. (2019). Analisis Pinjaman Online Oleh Fintech Dalam Kajian Hukum Perdata. Jurisprudentie, 6(2), 15-25. https://doi.org/https://doi.org/10.24252/jurisprudentie.v6i2.10501

Marta Widian Sari, A. N. (2020). Analyzing Several Factors That Influence People To Make Loans Online. JhSS Journal of Humanities and Social Studies, 4(2). https://doi.org/10.33751/jhss.v4i2.2492

Silalahi, A. K. (2021). Urgensi Undang-Undang Fintech:Peer To Peer Lending (P2p) Terkait Pandemi Covid-19. Jurnal Um-Tapsel, https://doi.org/http://dx.doi.org/10.31604/justitia.v8i1.283-304

Sitompul, M. G. (2018). Urgensi Legalitas Financial Technology (Fintech): Peer to Peer (P2p) Lending Di Indonesia. Journal Article Public Jurnal Yuridis UNAJA, 10(5). https://doi.org/10.5281/jyu.v1i2.428

Soekanto, S. (2010). Pengantar Penelitian Hukum. UII Press.

Vedian, I. (2017). Penerapan Costumer Due Dilligence (CDD) dalam Pencegahan Pendanaan Terorisme melalui Perbankan. Jurnal Hukum Bisnis Dan Investasi, 7(2), 74-87. https://doi.org/10.28932/di.v7i2.717 